\title{
População Population
}

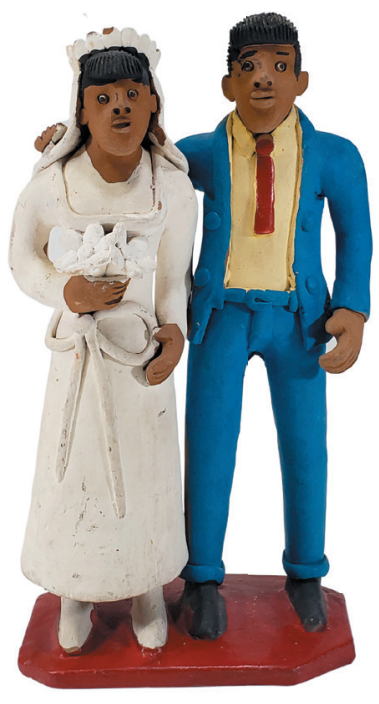

Casal de noivos, [S.d.]

Wedding couple, [undated]

Manuel Eudócio 


\section{Population}

Flávio Henrique Miranda de Araújo Freire ${ }^{1}$

\section{What would the 2020 Population Census show us in demographic terms?}

When the first cases of Severe Acute Respiratory Syndrome - SRAG, caused by SARS-CoV-2, the virus that causes the COVID-19, emerged in December 2019, in Wuhan - China, the dramatic impacts on the world population's health were hardly imagined, let alone the status of pandemic, determined by the World Health Organization - WHO. In such a context, the conduction of the 2020 Population Census was not possible.

Brazilian Population Censuses have been carried out every ten years since 1940, except for the 1991 Population Census. This regularity is important to portray the national demographic dynamics, in the Major Regions, Federation Units and Municipalities.

With the gap imposed by the COVID-19 pandemic, this text aims at showing - based on the analysis of the available population data, and on the trends of some demographic indicators and projections - an analysis of the Brazilian population to infer what could be found out by the 2020 Population Census.

$\overline{1 \mathrm{PhD}}$ in Demography, Professor at the Department of Demography and Actuarial Sciences and at the Postgraduate Program in Demography (PPGDem), Federal University of Rio Grande do Norte (UFRN). Member of the Brazilian Association of Population Studies (Abep). Researcher at the National Council for Scientific and Technological Development (CNPq). 


\section{População}

\section{Flávio Henrique Miranda de Araújo Freire ${ }^{1}$}

\section{O que o Censo Demográfico 2020 nos mostraria em termos demográficos?}

Quando os primeiros casos de Síndrome Respiratória Aguda Grave - SRAG, causados pelo SARS-CoV-2, vírus que dá origem à doença COVID-19, surgiram em dezembro de 2019, em Wuhan, na China, era difícil imaginar os impactos dramáticos na saúde da população mundial, com decretação do estado de pandemia pela Organização Mundial da Saúde (OMS) (World Health Organization - WHO). Diante desse cenário, não foi possível a realização do Censo Demográfico 2020.

Desde 1940 os censos demográficos brasileiros vêm sendo realizados a cada dez anos, com exceção do Censo Demográfico 1991. Tal periodicidade é importante, para que se conheça a tendência da dinâmica demográfica nacional, de suas regiões, Unidades da Federação e municípios.

Com a lacuna imposta pela pandemia de COVID-19, este texto busca, a partir de uma avaliação de dados populacionais disponíveis, tendência de alguns indicadores demográficos e projeções prospectivas, realizar uma análise da população brasileira, inferindo acerca do que se encontraria no Censo Demográfico 2020.

1 Doutor em Demografia. Professor do Departamento de Demografia e Ciências Atuariais e do Programa de Pós-graduação em Demografia (PPGDem), Universidade Federal do Rio Grande do Norte (UFRN). Membro da Associação Brasileira de Estudos Populacionais (Abep). Pesquisador do Conselho Nacional de Desenvolvimento Científico e Tecnológico (CNPq). 
In 2010, $84.36 \%$ of the Brazilian population lived in urban areas, which corresponds to $160,925,804$ Brazilians. The lowest percentage was in the Northeast $(73.13 \%)$ and the highest, in the Southeast, where 92.95\% of the population lived in urban areas (Tables 2.1 and 2.2). In 1940 , the urbanization rate in Brazil was of $31.24 \%$, reaching $55.92 \%$ in 1970 and $81.23 \%$ in 2000 , which reveals a strong trend of search for urban areas for living instead of the rural ones, and there are no evidences that indicate an inversion of this trend in the last decade. The Brazilian population has increased significantly, and they have chosen to live mainly in the cities.

Still concerning the spatial distribution of the population, considering the previous decades (Graph 2.5), the population growth in Brazil has been decreasing over time, and reached a geometric rate of annual average growth of $1.17 \%$ between 2000 and 2010 (Table 2.2). At the sub-national level, the North Region was the one with the highest population growth, with an average growth rate of $2.09 \%$ per year between 2000 and 2010, with a highlight to the states of Amapá and Roraima, with annual geometric growth rates of $3.45 \%$ and $3.34 \%$, respectively (Table 2.2 ). On the other hand, the South Region presented the lowest population growth in the country, from 2000 to 2010 , recording a geometric growth rate of $0.87 \%$, with a highlight to Rio Grande do Sul as the Brazilian state with the lowest population growth in the period, just $0.49 \%$ per year (Table 2.2 ). To contextualize what such a growth represents, the lowest range of population growth, according to the United Nations Population Division, Department of Economic and Social Affairs, comprises developed countries in Europe and North America, as well as Australia, New Zealand and Japan. Taking that group altogether, the annual average growth was of $0.42 \%$ between 2005 and 2010 (WORLD..., 2019).

The decrease in the pace of population growth results from the decline in mortality and birth rates, which is known in the specialized literature as demographic transition. The Brazilian mortality rate started its decline in the 1940s, whereas the fertility rate started decreasing as of the 1960s (BRITO, 2007). The pace of decline for both fertility and mortality was not the same among the Brazilian Major Regions and that explains the regional differences in the population growth rates. In 2010, the total fertility rate of the North Region estimated by the Brazilian Institute of Geography and Statistics (IBGE) was of 2.47 children per woman. In the South Region, the estimate of this indicator for 2010 was of 1.78 (CENSO..., 2010). 
Em 2010, 84,36\% da população brasileira vivia em áreas urbanas, equivalente a 160.925 .804 brasileiros, com o menor percentual no Nordeste $(73,13 \%)$ e o maior percentual no Sudeste, onde $92,95 \%$ da população viviam em áreas urbanas (Tabelas 2.1 e 2.2). Em 1940, a taxa de urbanização no Brasil era de 31,24\%, atingiu 55,92\%, em 1970, e 81,23\%, em 2000, o que mostra que há uma forte tendência da população procurar áreas urbanas para viver em detrimento de áreas rurais, e não há razão para acreditar numa inversão dessa tendência na última década. O Brasil aumentou substancialmente sua população, que passou a viver eminentemente nas cidades.

Ainda no que se refere à distribuição espacial da população, considerando décadas anteriores (Gráfico 2.5), o crescimento populacional no Brasil vem diminuindo com tempo, atingindo uma taxa geométrica de crescimento médio anual de 1,17\% entre 2000 e 2010 (Tabela 2.2). No nível subnacional, a Região Norte foi a que apresentou maior crescimento da população, com taxa de crescimento média de 2,09\% ao ano entre 2000 e 2010, com destaque para os Estados do Amapá e Roraima, com taxas geométricas anuais de crescimento de 3,45\% e 3,34\%, respectivamente (Tabela 2.2). Por outro lado, a Região Sul apresentou o menor crescimento populacional do País, entre 2000 e 2010, com taxa de crescimento geométrico igual a 0,87\%, destacando-se o Rio Grande do Sul como o estado brasileiro de menor crescimento populacional no período, apenas $0,49 \%$ ao ano (Tabela 2.2). Para se ter uma ideia do que representa esse baixo crescimento do Rio Grande do Sul, o estrato de menor crescimento populacional segundo a Divisão de População das Nações Unidas, do Departamento de Assuntos Econômicos, é composto por países mais desenvolvidos compreendidos pela Europa, América do Norte, Austrália, Nova Zelândia e Japão. Tomando este grupo como um todo, o crescimento médio anual foi de $0,42 \%$ entre 2005 e 2010 (WORLD..., 2019).

Esse decréscimo no ritmo do crescimento populacional é consequência da diminuição dos níveis de mortalidade e natalidade da população, conhecido na literatura como transição demográfica. A mortalidade brasileira iniciou seu declínio nos anos 1940 do século passado, enquanto a fecundidade começou a diminuir a partir da década de 1960 (BRITO, 2007). O ritmo de declínio, tanto de fecundidade quanto da mortalidade, não foi o mesmo ao longo das regiões brasileiras, e isso explica os diferenciais regionais nas taxas de crescimento populacional. Em 2010, a taxa de fecundidade total da Região Norte estimada pelo Instituto Brasileiro de Geografia e Estatística (IBGE) foi de 2,47 filhos por mulher. Na Região Sul, a estimativa desse indicador para 2010 foi de 1,78 (CENSO..., 2010). 
The regional diversity also shows in the population density. The North Region, which records the highest population growth in the country, has the lowest population density, with 4.12 people per square kilometer. The country has areas of high density and high urbanization rates, such as the Federal District, and areas as the states of Amazonas and Roraima, with a population density slightly above two people per square kilometer (Table 2.2). It is worth pointing out that the number of residents in the total area of a region, as Federation Units for example, is not the best indicator to analyze effectively the population density growth. As to the aforementioned examples, for instance, the Federal District has a much smaller area than the Amazonas State, and its population is practically all concentrated in the urban areas of Brasília and surroundings. In Amazonas, in turn, there is a considerable area of forests and Indigenous reserves.

Concerning age composition, Graph 2.1 presents the population pyramids of Brazil in the last three Population Censuses: 1991, 2000 and 2010. Comparing the three distributions by age, a clear narrowing down of the pyramid base is seen, from 2000 to 2010, as well as in the comparison between 1991 and 2000. There is also a gradual increase of the relative weight of the populations starting with the 25-29 age group (Graph 2.1).

This change in the age structure is another consequence of the demographic transition and it shows the aging process of the Brazilian population, even more prominent in the share of women, a reflex of the male mortality surplus, which is, to a great extent, due to external causes and circulatory system diseases (CALAZANS; QUEIROZ, 2020).

When the population pyramids of Graphs 2.1 and 2.2 are analyzed together, there is even more indication of the changes in the age structure, as the relative weight increase of the adult population. That occurs because the relative weight of births has already fallen significantly and there has not yet been enough time for the youth cohorts to reach the pyramid top, even with the mortality rate decline. This is the so-called demographic dividend, characterized by a low dependency ratio - ratio between inactive population (younger than 15 years old and aged 65 and over) and the active population (aged between 15 and 64) (BRITO, 2007).

Although the fertility trend showed a strong decrease up to 2010, the estimates are of stability at nearly 1.75 children per woman (Table 2.3). Fertility being kept at this level, below population replacement, will lead to a gradual decreasing number of births in the next years. 
A diversidade regional brasileira também aparece na densidade demográfica. A Região Norte, que ostenta o maior crescimento populacional, tem a menor densidade demográfica no País, com 4,12 habitantes por quilômetro quadrado. O País tem áreas com alta densidade demográfica e alta taxa de urbanização, como o Distrito Federal, e áreas como os Estados do Amazonas e Roraima, com densidade demográfica de um pouco mais de dois habitantes por quilômetro quadrado (Tabela 2.2). Cabe ressaltar que, o número de habitantes por área total de uma região, como as Unidades da Federação, efetivamente não é o melhor indicador para analisar o adensamento populacional. Para ficar nos exemplos citados, o Distrito Federal possui uma área muito menor que o Estado do Amazonas, e sua população está praticamente toda concentrada em área urbana de Brasília e entorno. No Amazonas, há uma área substancial de florestas e reservas indígenas.

No que tange a composição etária, o Gráfico 2.1 apresenta as pirâmides etárias da população brasileira nos últimos três Censos Demográficos: 1991, 2000 e 2010. Cotejando as três distribuições por idade, percebe-se claramente o estreitamento da base da pirâmide de 2010 com relação a de 2000, e deste com relação a 1991. Também se observa o aumento gradual do peso relativo das populações a partir do grupo etário 25 a 29 (Gráfico 2.1).

Essa mudança na estrutura etária é outra consequência da transição demográfica e evidencia o processo de envelhecimento da população brasileira, ainda mais proeminente na população feminina, reflexo da sobremortalidade masculina, em grande parte devido a causas externas e doenças do aparelho circulatório (CALAZANS; QUEIROZ, 2020).

Quando avaliamos as pirâmides etárias dos Gráficos 2.1 e 2.2 em conjunto, percebe-se ainda mais nuances acerca das alterações de estrutura etária, como o aumento do peso relativo da população adulta. Isso ocorre porque o peso relativo dos nascimentos já caiu de forma considerável e não houve tempo suficiente para as coortes jovens chegarem ao topo da pirâmide, mesmo diante do declínio da mortalidade. É o que se chama bônus demográfico, caracterizado por uma razão de dependência baixa (razão entre a população em idade inativa, menores de 15 anos e população com 65 anos ou mais, e a população em idade ativa, com idade entre 15 e 64 anos) (BRITO, 2007).

Se a tendência da fecundidade foi de forte declínio até 2010, as estimativas são de estabilidade por volta de 1,75 filhos por mulher na última década (Tabela 2.3). A fe- 
Besides, the declining trend of the relative weight of the female population in the quinquennial reproductive age groups (15 to 49 years of age) will turn live births, and, consequently, the groups aged 0 to 4 , into less and less representative in terms of relative weight in the population pyramid. Therefore, if at each five years there are smaller cohorts on the pyramid basis, likewise, every five years, there will be smaller age cohorts: 5 to 9, 10 to 14,15 to 19 , and so on so forth. ${ }^{2}$

It is known for a fact that mortality has also undergone a decreasing trend. IBGE projections and estimates reveal the drop of the Infant Mortality Rate (IMR) in Brazil for the last decade, from 17.22 deaths of children under one year of age per each 1000 live births in 2010 up to 11.56 , in 2020 (Table 2.3). Unless some extreme and completely unexpected trend comes up, the decline effect of infant mortality will not be enough to make it up for the very low fertility level, so as to increase the 0-4 age group in the short run. A direct consequence of such trend is the low dependency ratio in 2010, as well as in 2020, according to IBGE projections (PROJEÇÃO, 2020). That occurs because, if the youth cohorts are getting smaller, at some point, the age cohort of people entering the labor market - the so-called active age - will also lose some of its relative weight in the general age structure. On the other hand, with the general mortality at constant decline, as indicated by the increasing trend of life expectancy at birth (Table 2.3 and Graph 2.4), the population cohorts aged 65 and over will be more and more numerous. In the population pyramid of Graph 2.2, the populations of the 20-24 and 25-29 age ranges estimated for 2020, in Brazil, already show a smaller weight than the 2010 population for those two age groups. Regarding the pyramid top, the increasing relevance of the population aged 65 and over in 2020 against 2010 becomes quite evident. (Graph 2.2).

Graph 2.3 shows the behavior of the Crude Birth Rate (CBR) and Crude Death Rate (CDR) in the last decade which ratifies the present analysis. The CBR is almost regular in the first half of the decade, adding up to nearly 15 births per 1000 population (Table 2.3), with a slight decline in the second half, showing a downward trend and almost stabilization of the number of births per people. In turn, the CDR remains nearly stable, with a slight increase at the end of the decade, from 6.36 deaths per 1000 residents in 2010 to 6.56 in 2020 (Table 2.3).

$\overline{2.1}$ children per woman is the minimum fertility level capable of replacing a generation. 
cundidade mantida nesse patamar, abaixo do nível de reposição populacional2 ${ }^{2}$, levará a um número de nascimentos continuamente decrescente nos próximos anos. Além disso, a tendência declinante do peso relativo da população feminina em grupos etários quinquenais do período reprodutivo (15 a 49 anos) fará com que os nascimentos sobreviventes, por consequência o grupo etário de 0 a 4 anos, tenham cada vez menos peso relativo na pirâmide etária. Portanto, se a cada cinco anos temos coortes menores na base da pirâmide, também a cada quinquênio teremos coortes menores nas idades de 5 a 9, 10 a 14, 15 a 19 e assim por diante.

É fato que a mortalidade também tem tendência de declínio. As projeções e estimativas do IBGE revelam declínio da Taxa de Mortalidade Infantil (TMI) no Brasil para a última década, saindo de 17,22 mortes de menores de um ano para cada 1000 nascidos vivos em 2010 até atingir 11,56, em 2020 (Tabela 2.3). A menos que algum fenômeno extremo e totalmente fora de qualquer tendência ocorra, o efeito do declínio da mortalidade infantil não é suficiente para compensar o efeito de uma fecundidade muito baixa, ao ponto de aumentar o grupo etário de 0 a 4 anos no curto prazo. Uma consequência direta dessa tendência é a baixa razão de dependência em 2010, bem como em 2020 segundo projeções do IBGE (PROJEÇÃO, 2020). Isto ocorre porque, se as coortes jovens são cada vez menores, em algum momento as coortes com idade ao entrar no mercado de trabalho, ditas em idade ativa, também perderão peso relativo na estrutura etária geral. Por outro lado, com a mortalidade geral constantemente em declínio, como indica a tendência de aumento da esperança de vida ao nascer (Tabela 2.3 e Gráfico 2.4), as coortes de população com 65 anos ou mais serão cada vez mais numerosas. Na pirâmide etária do Gráfico 2.2, as populações dos grupos etários 20 a 24 e 25 a 29 estimadas para 2020, no Brasil, já têm peso relativo menor do que a população de 2010 para esses dois grupos etários. Com relação ao topo da pirâmide, fica evidente o aumento da importância da população acima dos 65 anos em 2020 com relação a 2010 (Gráfico 2.2).

O Gráfico 2.3 mostra o comportamento das Taxa Bruta de Natalidade (TBN) e Taxa Bruta de Mortalidade (TBM) na última década que ratifica a análise em pauta. A TBN é quase constante na primeira metade da década, com valor em torno de 15 nascimentos por 1000 habitantes (Tabela 2.3), declina muito levemente na segunda metade, evidenciando a tendência de diminuição e quase estabilização do número de nascimentos por habitantes. Já a TBM permanece praticamente constante, com

$\overline{2}$ 2,1 filhos por mulher é o nível mínimo de fecundidade que permite a reposição de uma geração. 
This result for the crude death rate seems contradictory, since the infant mortality rate shows a downward trend while life expectancy has been rising. That occurs because the CDR is a general rate, which divides the total deaths by the total general population, without measuring the different death risks for each age. As it does not consider the age structure of the population at each year, the oldest age structure in 2020 results in a greater total number of deaths, which does not imply a greater death risk by age. Actually, it is just the opposite, the expected population for 2020 is older because mortality across the age ranges was smaller, generating greater survival levels, as shown in the increasing series of life expectancy. Therefore, by dividing the total deaths by the total population, the result can look paradoxical, as the general volume of deaths is greater, and that occurs specifically because of the age composition effect.

This being said, what is the profile of the Brazilian population that would be revealed by the 2020 Census? The historical trend of the indicators and projections carried out by the IBGE (PROJEÇÃO, 2020) points out to a population of 211 million residents (Table 2.3), living in urban areas, with a quite young age structure, but at a fast transition towards aging, with a still low dependency ratio, around 45 persons at inactive age per each 100 at active age (between 15 and 64 years old). However, due to the strong decline of fertility along with the mortality drop, the latest version of the population projection of the IBGE indicates a fast aging process of the Brazilian population in the next decades, with a greater relative weight of the elderly and a lower relative weight of the children, youngsters and adults. The temporary and extremely positive window from the demographic perspective - in which the ratio between the active-age and inactiveage population is low, meaning an opportunity in the short-run to leverage the economic dynamism - is shutting down. 
um leve acréscimo no final da década, saindo de 6,36 óbitos por 1000 habitantes em 2010 para 6,56 em 2020 (Tabela 2.3).

Este resultado para a taxa bruta de mortalidade parece contraditório, na medida em que a mortalidade infantil tem tendência de queda e a esperança de vida vem aumentando. Isto ocorre porque a TBM é uma taxa geral, que divide o total de óbitos pelo total geral da população, sem mensurar os diferentes riscos de morte a cada idade. Por não considerar a estrutura etária da população a cada ano a estrutura etária mais velha em 2020 resulta em um número geral de óbitos maior, sem que isso reflita necessariamente maior risco de morte por idade. Na verdade, é justamente o contrário, a população esperada para 2020 é mais velha porque a mortalidade ao longo das idades foi menor, gerando maior sobrevivência, como demonstrado na série crescente de esperança de vida. Então, ao dividir apenas o total de óbitos pelo total da população, o resultado pode parecer paradoxal, porque o volume geral de óbitos é maior, e isso ocorre especificamente por efeito de composição etária.

Diante do cenário apresentado, qual o perfil da população brasileira que Censo Demográfico 2020 revelaria? A tendência histórica dos indicadores e as projeções realizadas pelo IBGE (PROJEÇÃO, 2020) apontam para uma população de 211 miIhões de habitantes (Tabela 2.3), vivendo em áreas urbanas, com estrutura etária ainda jovem, mas em rápida transição para o envelhecimento, com uma razão de dependência ainda baixa, girando em torno de 45 pessoas em idade inativa para cada 100 pessoas em idade ativa (entre 15 e 64 anos). No entanto, em decorrência do forte declínio da fecundidade, além do declínio da mortalidade, a última versão da projeção populacional do IBGE aponta para o acelerado processo de envelhecimento da população brasileira nas próximas décadas, com maior peso relativo da população idosa e menor peso relativo da população de crianças, jovens e adultos. A janela temporária e extremamente positiva do ponto de vista demográfico, onde a razão entre a população em idade inativa e a população em idade ativa é baixa, que significaria uma oportunidade conjuntural que poderia alavancar o dinamismo econômico, está se fechando. 


\section{References}

BRITO, F. A transição demográfica no Brasil: as possibilidades e os desafios para a economia e a sociedade. Belo Horizonte: UFMG, Centro de Desenvolvimento e Planejamento Regional da Faculdade de Ciências Econômicas, 2007.28 p. (Texto para discussão; 318). Available from: <http:// www.cedeplar.ufmg.br/pesquisas/td/TD\%20318.pdf>. Cited: May 2020.

CALAZANS, J. A; QUEIROZ, B. L. The adult mortality profile by cause of death in 10 Latin American countries (2000-2016). Revista Panamericana de Salud Publica, Washington, DC, v. 44, p. 1-9, 2020. Available from: < https://www. ncbi.nlm.nih.gov/pmc/articles/PMC6966090/>. Cited: May 2020.

CENSO demográfico 2010. Nupcialidade, fecundidadee migração: resultados da amostra. Rio de Janeiro: IBGE, 2010. Available from: < https://www.ibge. gov.br/estatisticas/sociais/populacao/9662-censo-demografico-2010. html?edicao=9750\&t=o-que-e $>$. Cited: May 2020.

PROJEÇÃO da população do Brasil e Unidades da Federação por sexo e idade: 2010-2060. Revisão 2018. Rio de Janeiro: IBGE, 2020. Tabelas. Available from: < https://www.ibge.gov.br/estatisticas/sociais/populacao/9109-projecaoda-populacao.html?=\&t=resultados $>$. Cited: May 2020.

WORLD population prospects 2019: highlights. New York: United Nations, Department of Economic and Social Affairs, 2019. Available from: < https:// www.un.org/development/desa/publications/world-population-prospects2019-highlights.html>. Cited: May 2020.

Translated by: Gisele Flores Caldas Manhães. 


\section{Referências}

BRITO, F. A transição demográfica no Brasil: as possibilidades e os desafios para a economia e a sociedade. Belo Horizonte: UFMG, Centro de Desenvolvimento e Planejamento Regional da Faculdade de Ciências Econômicas, 2007. 28 p. (Texto para discussão; 318). Disponível em: <http://www.cedeplar.ufmg.br/pesquisas/td/TD\%20 318.pdf>. Acesso em: maio 2020.

CALAZANS, J. A; QUEIROZ, B. L. The adult mortality profile by cause of death in 10 Latin American countries (2000-2016). Revista Panamericana de Salud Publica, Washington, DC, v. 44, p. 1-9, 2020. Disponível em: < https://www.ncbi.nlm.nih.gov/pmc/articles/ PMC6966090/>. Acesso em: maio 2020.

CENSO demográfico 2010. Nupcialidade, fecundidade e migração: resultados da amostra. Rio de Janeiro: IBGE, 2010. Disponível em: < https://www.ibge.gov.br/ estatisticas/sociais/populacao/9662-censo-demografico-2010.html?edicao=9750\&t=oque-e>. Acesso em: maio 2020.

PROJEÇÃO da população do Brasil e Unidades da Federação por sexo e idade: 20102060. Revisão 2018. Rio de Janeiro: IBGE, 2020. Tabelas. Disponível em: < https:// www.ibge.gov.br/estatisticas/sociais/populacao/9109-projecao-da-populacao. html?=\&t=resultados $>$. Acesso em: maio 2020.

WORLD population prospects 2019: highlights. New York: United Nations, Department of Economic and Social Affairs, 2019. Disponível em: < https://www.un.org/ development/desa/publications/world-population-prospects-2019-highlights.html>. Acesso em: maio 2020. 


\title{
Gráfico 2.1 - Composição relativa da população residente, por sexo e grupos de idade - 1991/2010
}

\author{
Graph 2.1 - Relative composition of the resident population, \\ by sex and age groups - 1991/2010
}

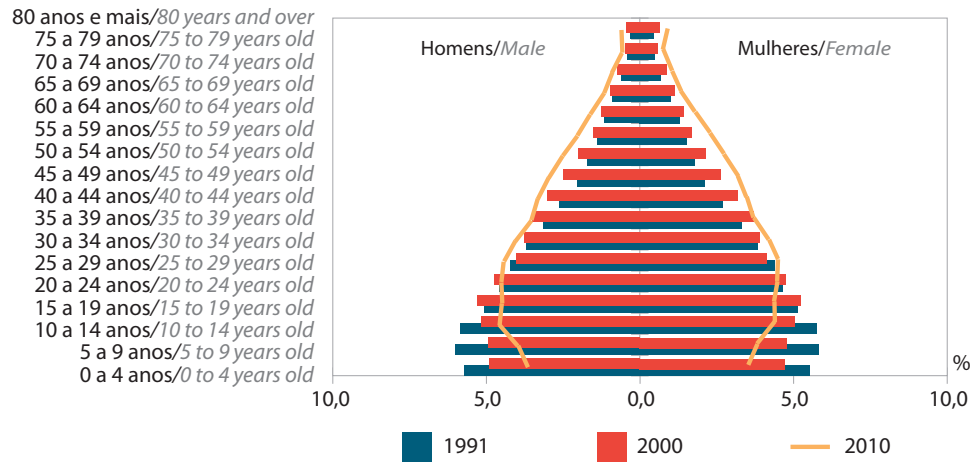

Fonte/Source: IBGE, Censo Demográfico 1991/2010.

\section{Gráfico 2.2 - Projeção da população - 2010/2020 \\ Graph 2.2 - Population projections - 2000/2020}

80 anos e mais/80 years and over

75 a 79 anos/75 to 79 years old

70 a 74 anos $/ 70$ to 74 years old

65 a 69 anos/65 to 69 years old

60 a 64 anos $/ 60$ to 64 years old 55 a 59 anos $/ 55$ to 59 years old 50 a 54 anos $/ 50$ to 54 years old 45 a 49 anos $/ 45$ to 49 years old 40 a 44 anos/40 to 44 years old 35 a 39 anos/35 to 39 years old 30 a 34 anos $/ 30$ to 34 years old 25 a $29 \mathrm{anos} / 25$ to 29 years old 20 a 24 anos/20 to 24 years old 15 a 19 anos/15 to 19 years old 10 a 14 anos/10 to 14 years old 5 a 9 anos $/ 5$ to 9 years old 0 a 4 anos $/ 0$ to 4 years old

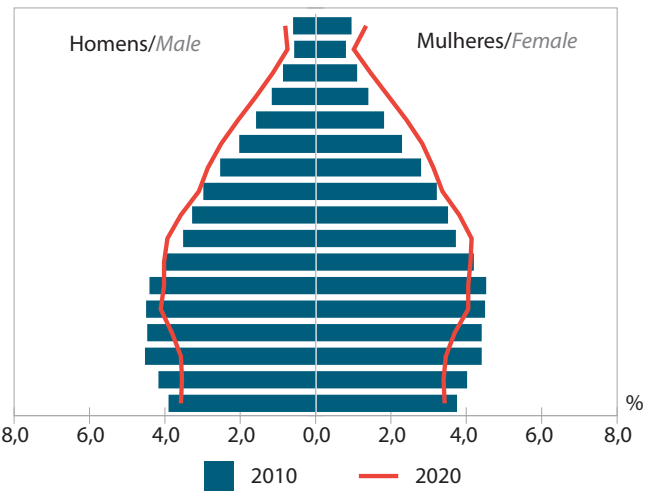

Fonte/Source: IBGE, Diretoria de Pesquisas, Coordenação de População e Indicadores Sociais, Projeção da População do Brasil por Sexo e Idade para o Período 2010-2060 - Revisão 2018. 
por 1000 hab./per 1,000 inhab.

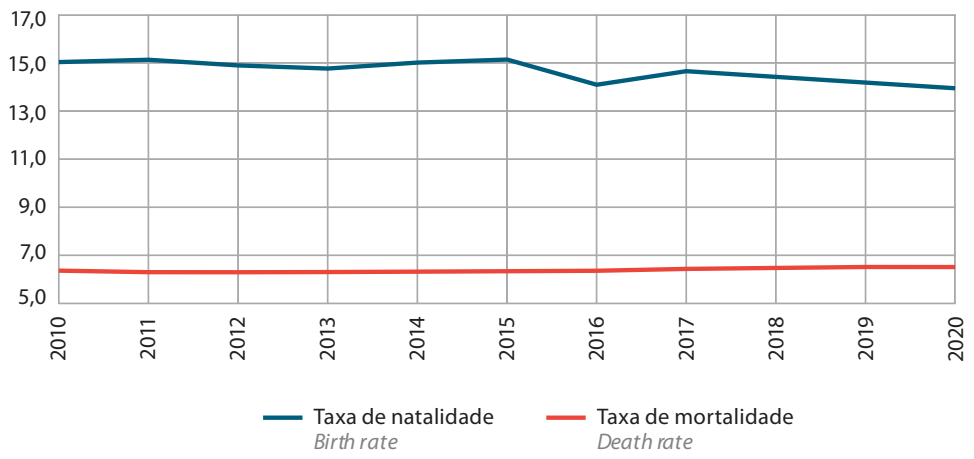

Fonte/Source: IBGE, Diretoria de Pesquisas, Coordenação de População e Indicadores Sociais. Projeção da população do Brasil e Unidades da Federação por sexo e idade para o período 2010-2060- Revisão 2018.

\section{Gráfico 2.4 - Esperança de vida ao nascer - 1930/2020}

Graph 2.4 - Life expectancy at birth - 1930/2020

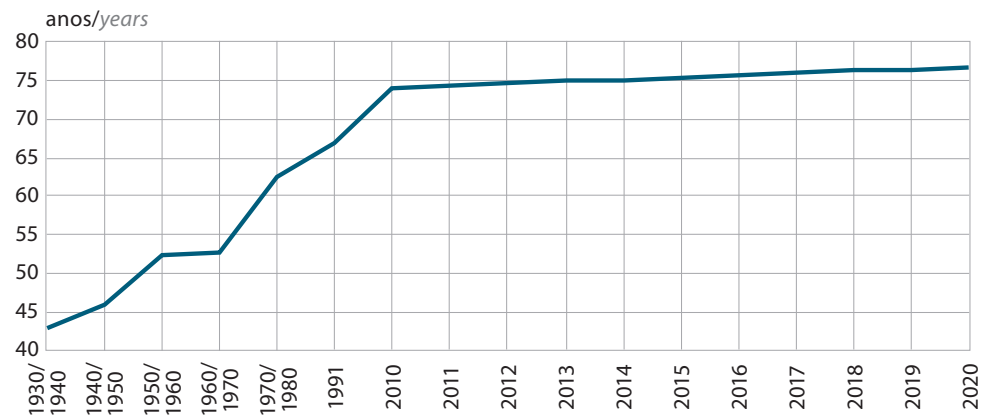

Fonte/Source: IBGE, Diretoria de Pesquisas, Coordenação de População e Indicadores Sociais, Tábuas Construídas e Projeção da População do Brasil e Unidades da Federação por sexo e idade para o período 2010-2060- Revisão 2018. 
Tabela 2.1 - População residente, por situação do domicílio e sexo - 2010

Table 2.1 - Resident population, by urban/rural housing unit and sex-2010

(continua/to be continued)

\begin{tabular}{|c|c|c|c|c|c|}
\hline \multirow{3}{*}{$\begin{array}{l}\text { Grandes Regiões } \\
\text { e } \\
\text { Unidades da Federação/ } \\
\text { Major Regions and } \\
\text { Federation Units }\end{array}$} & \multicolumn{5}{|c|}{ População residente/ Resident population } \\
\hline & \multirow{2}{*}{$\begin{array}{l}\text { Total/ } \\
\text { Total }\end{array}$} & \multicolumn{2}{|c|}{$\begin{array}{c}\text { Situação do domicílio/ } \\
\text { Housing unit }\end{array}$} & \multicolumn{2}{|c|}{$\begin{array}{l}\text { Sexo/ } \\
\text { Sex }\end{array}$} \\
\hline & & $\begin{array}{l}\text { Urbana/ } \\
\text { Urban }\end{array}$ & $\begin{array}{l}\text { Rural/ } \\
\text { Rural }\end{array}$ & $\begin{array}{l}\text { Homens/ } \\
\text { Male }\end{array}$ & $\begin{array}{l}\text { Mulheres/ } \\
\text { Female }\end{array}$ \\
\hline $\begin{array}{l}\text { Brasil/ } \\
\text { Brazil }\end{array}$ & 190755799 & 160925804 & 29829995 & 93406990 & 97348809 \\
\hline $\begin{array}{l}\text { Norte/ } \\
\text { North }\end{array}$ & 15864454 & 11664509 & 4199945 & 8004915 & 7859539 \\
\hline Rondônia & 1562409 & 1149180 & 413229 & 795157 & 767252 \\
\hline Acre & 733559 & 532279 & 201280 & 368324 & 365235 \\
\hline Amazonas & 3483985 & 2755490 & 728495 & 1753179 & 1730806 \\
\hline Roraima & 450479 & 344859 & 105620 & 228859 & 221620 \\
\hline Pará & 7581051 & 5191559 & 2389492 & 3821837 & 3759214 \\
\hline Amapá & 669526 & 601036 & 68490 & 335135 & 334391 \\
\hline Tocantins & 1383445 & 1090106 & 293339 & 702424 & 681021 \\
\hline $\begin{array}{l}\text { Nordeste/ } \\
\text { Northeast }\end{array}$ & 53081950 & 38821258 & 14260692 & 25909046 & 27172904 \\
\hline Maranhão & 6574789 & 4147149 & 2427640 & 3261515 & 3313274 \\
\hline Piauí & 3118360 & 2050959 & 1067401 & 1528422 & 1589938 \\
\hline Ceará & 8452381 & 6346569 & 2105812 & 4120088 & 4332293 \\
\hline Rio Grande do Norte & 3168027 & 2464991 & 703036 & 1548887 & 1619140 \\
\hline Paraíba & 3766528 & 2838678 & 927850 & 1824379 & 1942149 \\
\hline Pernambuco & 8796448 & 7052210 & 1744238 & 4230681 & 4565767 \\
\hline Alagoas & 3120494 & 2297860 & 822634 & 1511767 & 1608727 \\
\hline Sergipe & 2068017 & 1520366 & 547651 & 1005041 & 1062976 \\
\hline Bahia & 14016906 & 10102476 & 3914430 & 6878266 & 7138640 \\
\hline
\end{tabular}


Tabela 2.1 - População residente, por situação do domicílio e sexo - 2010

Table 2.1 - Resident population, by urban/rural housing unit and sex-2010

(conclusão/concluded)

\begin{tabular}{|c|c|c|c|c|c|}
\hline \multirow{3}{*}{$\begin{array}{c}\text { Grandes Regiões } \\
\text { e } \\
\text { Unidades da Federação/ } \\
\text { Major Regions and } \\
\text { Federation Units }\end{array}$} & \multicolumn{5}{|c|}{ População residente/ Resident population } \\
\hline & \multirow{2}{*}{$\begin{array}{l}\text { Total/ } \\
\text { Total }\end{array}$} & \multicolumn{2}{|c|}{$\begin{array}{c}\text { Situação do domicílio/ } \\
\text { Housing unit }\end{array}$} & \multicolumn{2}{|c|}{$\begin{array}{l}\text { Sexo/ } \\
\text { Sex }\end{array}$} \\
\hline & & $\begin{array}{l}\text { Urbana/ } \\
\text { Urban }\end{array}$ & $\begin{array}{l}\text { Rural/ } \\
\text { Rural }\end{array}$ & $\begin{array}{l}\text { Homens/ } \\
\text { Male }\end{array}$ & $\begin{array}{l}\text { Mulheres/ } \\
\text { Female }\end{array}$ \\
\hline $\begin{array}{l}\text { Sudeste/ } \\
\text { Southeast }\end{array}$ & 80364410 & 74696178 & 5668232 & 39076647 & 41287763 \\
\hline Minas Gerais & 19597330 & 16715216 & 2882114 & 9641877 & 9955453 \\
\hline Espírito Santo & 3514952 & 2931472 & 583480 & 1731218 & 1783734 \\
\hline Rio de Janeiro & 15989929 & 15464239 & 525690 & 7625679 & 8364250 \\
\hline São Paulo & 41262199 & 39585251 & 1676948 & 20077873 & 21184326 \\
\hline $\begin{array}{l}\text { Sul/ } \\
\text { South }\end{array}$ & 27386891 & 23260896 & 4125995 & 13436411 & 13950480 \\
\hline Paraná & 10444526 & 8912692 & 1531834 & 5130994 & 5313532 \\
\hline Santa Catarina & 6248436 & 5247913 & 1000523 & 3100360 & 3148076 \\
\hline Rio Grande do Sul & 10693929 & 9100291 & 1593638 & 5205057 & 5488872 \\
\hline $\begin{array}{l}\text { Centro-Oeste/ } \\
\text { Central-West }\end{array}$ & 14058094 & 12482963 & 1575131 & 6979971 & 7078123 \\
\hline Mato Grosso do Sul & 2449024 & 2097238 & 351786 & 1219928 & 1229096 \\
\hline Mato Grosso & 3035122 & 2482801 & 552321 & 1549536 & 1485586 \\
\hline Goiás & 6003788 & 5420714 & 583074 & 2981627 & 3022161 \\
\hline $\begin{array}{l}\text { Distrito Federal } \\
\text { Federal District }\end{array}$ & 2570160 & 2482210 & 87950 & 1228880 & 1341280 \\
\hline
\end{tabular}

Fonte/Source: IBGE, Censo Demográfico 2010. 
Tabela 2.2 - Indicadores demográficos - 2010

Table 2.2 - Demographic indicators - 2010

(continua/to be continued)

\begin{tabular}{|c|c|c|c|c|}
\hline $\begin{array}{l}\text { Grandes Regiões } \\
\text { e } \\
\text { Unidades da } \\
\text { Federação/ } \\
\text { Major Regions and } \\
\text { Federation Units }\end{array}$ & $\begin{array}{l}\text { Taxa de } \\
\text { urbani- } \\
\text { zação } \\
(\%) / \\
\text { Urbanization } \\
\text { rate (\%) }\end{array}$ & $\begin{array}{l}\text { Taxa média } \\
\text { geométrica de } \\
\text { crescimento } \\
\text { anual } \\
(2000 / 2010) / \\
\text { Average } \\
\text { geometric } \\
\text { rate of annual } \\
\text { Increase } \\
\text { (2000/2010) }\end{array}$ & $\begin{array}{c}\text { Densidade } \\
\text { demográfica } \\
\left(\text { hab. } / \mathrm{km}^{2}\right) / \\
\text { Demographic } \\
\text { density } \\
\text { (inhab. } / \mathrm{km}^{2} \text { ) }\end{array}$ & $\begin{array}{l}\text { Coeficiente } \\
\text { de } \\
\text { mascu- } \\
\text { linidade/ } \\
\text { Ratio of } \\
\text { males to } \\
\text { females }\end{array}$ \\
\hline $\begin{array}{l}\text { Brasil/ } \\
\text { Brazil }\end{array}$ & 84,36 & 1,17 & 22,43 & 95,95 \\
\hline $\begin{array}{l}\text { Norte/ } \\
\text { North }\end{array}$ & 73,53 & 2,09 & 4,12 & 101,85 \\
\hline Rondônia & 73,55 & 1,25 & 6,58 & 103,64 \\
\hline Acre & 72,56 & 2,78 & 4,47 & 100,85 \\
\hline Amazonas & 79,09 & 2,16 & 2,23 & 101,29 \\
\hline Roraima & 76,55 & 3,34 & 2,01 & 103,27 \\
\hline Pará & 68,48 & 2,04 & 6,07 & 101,67 \\
\hline Amapá & 89,77 & 3,45 & 4,69 & 100,22 \\
\hline Tocantins & 78,80 & 1,80 & 4,98 & 103,14 \\
\hline $\begin{array}{l}\text { Nordeste/ } \\
\text { Northeast }\end{array}$ & 73,13 & 1,07 & 34,15 & 95,35 \\
\hline Maranhão & 63,08 & 1,52 & 19,81 & 98,44 \\
\hline Piauí & 65,77 & 0,93 & 12,40 & 96,13 \\
\hline Ceará & 75,09 & 1,30 & 56,76 & 95,10 \\
\hline Rio Grande do Norte & 77,81 & 1,33 & 59,99 & 95,66 \\
\hline Paraíba & 75,37 & 0,90 & 66,70 & 93,94 \\
\hline Pernambuco & 80,17 & 1,06 & 89,63 & 92,66 \\
\hline Alagoas & 73,64 & 1,01 & 112,33 & 93,97 \\
\hline Sergipe & 73,52 & 1,49 & 94,35 & 94,55 \\
\hline Bahia & 72,07 & 0,70 & 24,82 & 96,35 \\
\hline
\end{tabular}


Tabela 2.2 - Indicadores demográficos - 2010

Table 2.2 - Demographic indicators - 2010

(conclusão/concluded)

\begin{tabular}{|c|c|c|c|c|}
\hline $\begin{array}{c}\text { Grandes Regiões } \\
\text { e } \\
\text { Unidades da } \\
\text { Federação/ } \\
\text { Major Regions and } \\
\text { Federation Units }\end{array}$ & $\begin{array}{c}\text { Taxa de } \\
\text { urbani- } \\
\text { zação } \\
(\%) / \\
\text { Urbanization } \\
\text { rate (\%) }\end{array}$ & $\begin{array}{l}\text { Taxa média } \\
\text { geométrica de } \\
\text { crescimento } \\
\text { anual } \\
(2000 / 2010) / \\
\text { Average } \\
\text { geometric } \\
\text { rate of annual } \\
\text { Increase } \\
\text { (2000/2010) }\end{array}$ & $\begin{array}{c}\text { Densidade } \\
\text { demográfica } \\
\left(\text { hab. } / \mathrm{km}^{2}\right) / \\
\text { Demographic } \\
\text { density } \\
\left.\text { (inhab. } / \mathrm{km}^{2}\right)\end{array}$ & $\begin{array}{l}\text { Coeficiente } \\
\quad \text { de } \\
\text { mascu- } \\
\text { linidade/ } \\
\text { Ratio of } \\
\text { males to } \\
\text { females }\end{array}$ \\
\hline $\begin{array}{l}\text { Sudeste/ } \\
\text { Southeast }\end{array}$ & 92,95 & 1,05 & 86,92 & 94,64 \\
\hline Minas Gerais & 85,29 & 0,91 & 33,41 & 96,85 \\
\hline Espírito Santo & 83,40 & 1,27 & 76,25 & 97,06 \\
\hline Rio de Janeiro & 96,71 & 1,06 & 365,23 & 91,17 \\
\hline São Paulo & 95,94 & 1,09 & 166,25 & 94,78 \\
\hline $\begin{array}{l}\text { Sul/ } \\
\text { South }\end{array}$ & 84,93 & 0,87 & 48,58 & 96,32 \\
\hline Paraná & 85,33 & 0,89 & 52,40 & 96,56 \\
\hline Santa Catarina & 83,99 & 1,55 & 65,29 & 98,48 \\
\hline Rio Grande do Sul & 85,10 & 0,49 & 39,79 & 94,83 \\
\hline $\begin{array}{l}\text { Centro-Oeste/ } \\
\text { Central-West }\end{array}$ & 88,80 & 1,91 & 8,75 & 98,61 \\
\hline Mato Grosso do Sul & 85,64 & 1,66 & 6,86 & 99,25 \\
\hline Mato Grosso & 81,80 & 1,94 & 3,36 & 104,30 \\
\hline Goiás & 90,29 & 1,84 & 17,65 & 98,66 \\
\hline Distrito Federal/Federal District & 96,58 & 2,28 & 444,07 & 91,62 \\
\hline
\end{tabular}

Fonte/Source: IBGE, Censo Demográfico 2010. 
Tabela 2.3 - Projeções de população e taxas - 2010-2020

Table 2.3 - Population projections and rates - 2010-2020

\begin{tabular}{|c|c|c|c|c|c|c|}
\hline $\begin{array}{l}\text { Ano/ } \\
\text { Year }\end{array}$ & $\begin{array}{l}\text { População/ } \\
\text { Population }\end{array}$ & $\begin{array}{c}\text { Taxa } \\
\text { bruta } \\
\text { de natalidade } \\
\text { (por } 1000 \text { hab.)/ } \\
\text { Crude live } \\
\text { birth rate } \\
\text { (per 1,000 resid.) }\end{array}$ & $\begin{array}{c}\text { Taxa } \\
\text { bruta } \\
\text { de mortalidade } \\
\text { (por } 1000 \text { hab.)/ } \\
\text { Crude } \\
\text { death rate } \\
\text { (per 1,000 resid.) }\end{array}$ & $\begin{array}{c}\text { Esperança } \\
\text { de vida } \\
\text { ao nascer/ } \\
\text { Life } \\
\text { expectancy } \\
\text { at birth }\end{array}$ & $\begin{array}{c}\text { Taxa de } \\
\text { mortalidade } \\
\text { infantil } \\
\text { (por } 1000 \\
\text { nascidos } \\
\text { vivos)/ Infant } \\
\text { mortality rate } \\
\text { (per 1,000 } \\
\text { live births) }\end{array}$ & $\begin{array}{l}\text { Taxa } \\
\text { de } \\
\text { fecundi- } \\
\text { dade } \\
\text { total/ } \\
\text { Total } \\
\text { fertility } \\
\text { rate }\end{array}$ \\
\hline 2010 & 194890682 & 15,08 & 6,36 & 73,86 & 17,22 & 1,75 \\
\hline 2011 & 196603732 & 15,13 & 6,35 & 74,20 & 16,43 & 1,76 \\
\hline 2012 & 198314934 & 14,89 & 6,34 & 74,52 & 15,69 & 1,75 \\
\hline 2013 & 200004188 & 14,77 & 6,35 & 74,84 & 15,02 & 1,74 \\
\hline 2014 & 201717541 & 15,01 & 6,37 & 75,14 & 14,40 & 1,78 \\
\hline 2015 & 203475683 & 15,09 & 6,39 & 75,44 & 13,82 & 1,80 \\
\hline 2016 & 205156587 & 14,14 & 6,41 & 75,72 & 13,29 & 1,70 \\
\hline 2017 & 206804741 & 14,61 & 6,44 & 75,99 & 12,81 & 1,78 \\
\hline 2018 & 208494900 & 14,41 & 6,47 & 76,25 & 12,35 & 1,77 \\
\hline 2019 & 210147125 & 14,20 & 6,51 & 76,50 & 11,94 & 1,77 \\
\hline 2020 & 211755692 & 13,99 & 6,56 & 76,74 & 11,56 & 1,76 \\
\hline
\end{tabular}

Fonte/Source: IBGE, Diretoria de Pesquisas, Coordenação de População e Indicadores Sociais, Gerência de Estudos e Análises da Dinâmica Demográfica. Projeção da população do Brasil e Unidades da Federação por sexo e idade para o período 2010-2060- Revisão 2018. 
Gráfico 2.5 - Taxa média geométrica de crescimento anual - 1940/2010

Graph 2.5 - Average geometric rate of annual increase - 1940/2010

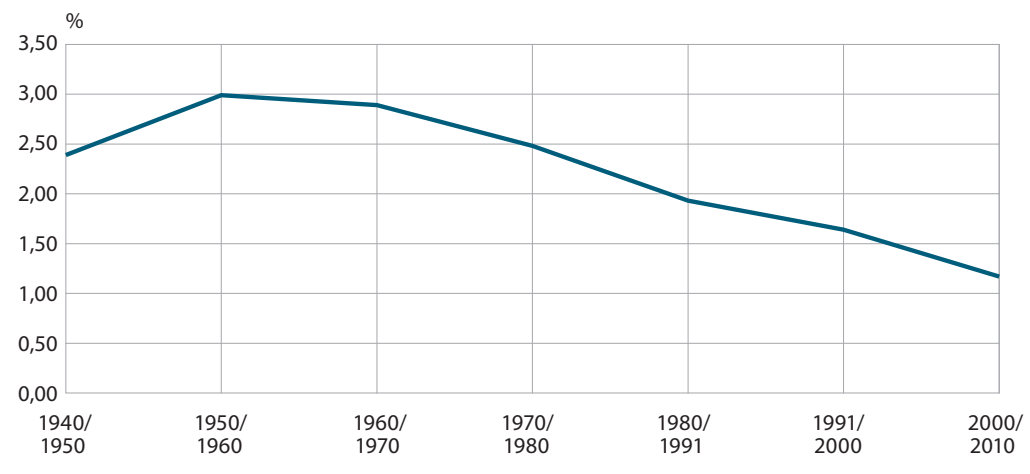

Fonte/Source: IBGE, Censo Demográfico 1940/2010. 